\title{
Analisis Penerapan Pengakuan Pendapatan Kontrak Konstruksi Berdasarkan PSAK 34
}

\author{
Riki Subagja dan Didit Pradipto \\ Program Studi Akuntansi, Institut Bisnis dan Informatika Kesatuan \\ Bogor, Indonesia \\ E-Mail: rsubagja1509@gmail.com
}

\begin{abstract}
This study aims to analyze the implementation of contract revenue recognition based on PSAK 34. The problem that is often faced by companies that are particularly engaged in the field of construction services in the recognition of income is the method of revenue recognition what should be used or applied, because there are differences in recognition between the one method with others. Especially if a project is done is more than a year or the so-called Long-term project. In addition, the presentation of financial statements of income recognition in each accounting period must be reported in accordance with generally accepted Accounting Standards (PSAK No. 34 concerning Construction Contracts). There is only one method used or applied that is the percentage completion method. The percentage method recognizes income with two approaches, based on physical progress and cost-to-cost. PT X as a construction service company uses the percentage of completion method with a physical progress approach (Physical progress) in the recognition of his opinion for both long-term contract and short-term contract. The results of this study conclude that the accounting treatment of the application of revenue recognition of construction services by using the percentage of completion method with physical progress approach on PT X is in conformity with the accounting standards set in PSAK No. 34. However, when compared to revenue recognition using the percentage of completion method with a cost-to-cost approach the firm can recognize the revenue and expenses more to illustrate or show a more proportional calculation because it corresponds to the costs incurred or poured out.
\end{abstract}

Keywords: revenue recognition, expense recognition, PSAK no. 34

\section{PENDAHULUAN}

Perusahaan yang bergerak dibidang konstruksi dalam menyelesaikan suatu pekerjaan atau proyek membutuhkan waktu kurang dalam satu tahun yaitu kontrak jangka pendek, dan ada yang lebih dari satu tahun yang biasa disebut kontrak jangka panjang. Proyek yang dilakukan dengan kontrak jangka panjang dalam pengakuan pendapatan menjadi sebuah hal yang mendapat perhatian lebih, karena sering terdapat dan terindikasi sebuah masalah. Hal ini disebabkan karena laporan keuangan harus dibuat sementara pekerjaan proyek masih belum selesai, sehingga perlu dibuat penaksiran berapa jumlah pendapatan yang harus diakui selama tahun berjalan. Kesalahan dalam pengakuan pendapatan tersebut akan menghasilkan laporan keuangan yang tidak andal dan relevan, serta akan mempersulit manajemen dan pihak yang memiliki kepentingan dalam mengambil sebuah keputusan.

PT X yang menjadi objek riset penulis merupakan suatu perusahaan yang bergerak dibidang jasa konstruksi yang berhubungan dengan alat-alat berat, pembangunan, pemasangan serta pembongkaran. Pelaksanaan suatu pekerjaan atau proyek dilakukan setelah adanya permintaan dari pihak pemberi kerja. PT X mengakui pendapatan menggunakan metode persentase penyelesaian untuk semua proyek, baik jangka panjang maupun jangka pendek.

\section{JIAKES}

Jurnal Ilmiah Akuntansi Kesatuan Vol. 7 No. 3, 2019 pg. 391-396 ISSN $2337-7852$ 
Revenue and

Expenses

Recognition

392

Dalam perusahaan konstruksi terdapat dua metode pengakuan pendapatan yaitu metode kontrak selesai, dan metode persentase penyelesaian. Metode kontrak selesai mengakui sebuah pendapatan dan laba kotor pada saat kontrak diselesaikan secara keseluruhan. Sedangkan untuk metode persentase penyelesain sendiri mengakui sebuah pendapatan biaya dan laba kotor sesuai dengan persentase pekerjaan yang diselesaikan dalam tiap periode yang berjalan. Untuk metode persentase penyelesaian memiliki dua pendekatan yaitu metode pendekatan fisik dan metode pendekatan cost-to-cost. Dengan adanya perbedaan pendekatan dalam metode pengakuan pendapatan persentase penyelesaian, maka perusahaan konstruksi dihadapkan pada permasalahan bagaimana menetukan pengakuan pendapatan yang tepat, terutama pada proyek-proyek jangka panjang. Sehingga laporan keuangan dapat disajikan secara wajar sesuai dengan kinerja perusahaan pada periode tersebut.

Akibat yang timbul jika pencatatan akuntansi perusahaan tidak dilaksanakan secara konsisten dan sesuai standar akuntansi yang berlaku adalah laporan keuangan yang tidak dapat menggambarkan keadaan manajemen tidak akurat karena laporan keuangan menunjukan informasi yang tidak andal dan relevan.

\section{TINJAUAN PUSTAKA}

Menurut PSAK 34 (Revisi 2010), Kontrak Konstruksi adalah suatu kontrak yang dinegosiasikan secara khusus untuk konstruksi suatu aset atau suatu kombinasi aset yang berhubungan erat satu sama lain atau saling tergantung dalam hal rancangan, teknologi, dan fungsi atau tujuan pokok penggunaan. Prinsip penandingan (matching principle) menyatakan bahwa beban harus diakui dalam periode yang sama dengan pendapatan yang terkait. Prinsip penandingan menyatakan bahwa beban-beban harus diakui dalam periode yang sama sebagai satu kesatuan dengan pendapatan.

Terkait dengan Belkaoui (2006:221 dalam Ratunuman:2013) menyata-kan bahwa hubungan antara pendapatan dan beban dalam proses menandingkan tergantung pada salah satu dari 4 (empat) kriteria berikut:

1. Penandingan langsung yang telah terpakai (expired cost) dengan suatu pendapatan (misalnya harga pokok penjualan dikaitkan dengan penjualan terkait).

2. Penandingan langsung dari beban yang telah terpakai pada periode tersebut (misalnya, gaji karyawan untuk periode tersebut).

3. Alokasi beban sepanjang periode yang memperoleh manfaat (misalnya, depresiasi).

4. Menjadikan beban semua biaya lain dalam peride terjadinya, kecuali jika dapat ditunjukan bahwa biaya tersebut masih memiliki manfaat di masa mendatang.

Berdasarkan empat kriteria di atas dapat disimpulkan bahwa yang dapat ditandingkan dengan pendapatan periode berjalan adalah beban yang telah terpakai (expired cost) dan menciptakan hasil dan manfaat untuk mendapatkan pendapatan. Sedangkan untuk beban yang belum terpakai akan dicatat sebagai aktiva tidak akan dicantumkan atau ditandingkan dengan pendapatan sebagai beban periode berjalan. Beban yang belum terpakai tersebut baru akan dibebankan ke pendapatan pada periode di masa yang akan datang pada saat terciptanya suatu manfaat.

Metode persentase penyelesaian (percentage of completion method) mengakui pendapatan, biaya, dan laba kotor sesuai dengan tercapainya kemajuan ke arah penyelesaian kontrak jangka panjang. Menunda pengakuan pos-pos ini sampai seluruh kontrak diselesaikan berarti salah menyajikan upaya (biaya) dan pencapaian (pendapatan) dalam periode akuntansi interim. Untuk menerapkan metode persentase penyelesaian, perusahaan harus mempunyai beberapa dasar atau standar untuk mengukur kemajuan ke arah penyelesaian pada tanggal interim tertentu.

Ada dua pendekatan dalam metode persentase penyelesaian yang dapat digunakan untuk mengakui pendapatan, yaitu:

1. Pendekatan fisik

2. Pendekatan biaya 
Untuk perhitungan persentase penyelesaian dengan pendekatan biaya, salah satu metodenya adalah dengan cost-to-cost basis. Menurut Kieso, Weygandt, dan Warfield (2014:915) rumusan dari cost-to-cost basis adalah sebagai berikut:

Biaya yang terjadi sampai saat ini Estimasi total biaya terkini

Terkait dengan Dwi Martani (2016:207) menyebutkan dalam kondisi ketika metode persentase penyelesaian tidak dapat digunakan, maka metode ini pendapatan hanya diakui sebesar biaya yang telah terjadi sepanjang biaya tersebut diperkirakan dapat terpulihkan. Ketika semua biaya telah diakui maka laba baru dapat diakui. Perusahaan mengakumulasikan biaya konstruksi dalam suatu akun yaitu pekerjaan dalam proses (construction in process), dan mengakumulasi penagihan termin dalam akun kontra yaitu termin (progress billing).

\section{METODOLOGI PENELITIAN}

Metode analisis data yang digunakan adalah metode deskriptif kualitatif dengan menggunakan analisis deskriptif komparatif. Dengan menggunakan metode deskriptif kualitatif, data yang diperoleh dianalisis secara kualitatif yaitu dengan mengkaji, memaparkan, menelaah dan menjelaskan data-data yang diperoleh untuk mendapatkan gambaran yang jelas dan menyeluruh tentang perlakuan akuntansi dalam pengakuan pendapatan kontrak di perusahaan konstruksi. Serta dengan analisis komparatif dilakukan dengan cara membandingkan teori dan praktik dalam pengakuan pendapatan konstruksi diperusahaan dengan perlakuan akuntansi berdasarkan Pernyataan Standar Akuntansi Keuangan (PSAK) 34 mengenai pendapatan konstrukssi

\section{HASIL DAN PEMBAHASAN}

\section{Pengakuan Pendapatan Konstruksi di PT X - Metode Persentase Penyelesaian (physical progress)}

Dalam perhitungan pengakuan pendapatan berdasarkan metode persentase penyelesaian dengan pendekatan progres fisik (physical progress) dalam mengakui pendapatan yang persentasenya ditentukan berdasarkan opname lapangan yang dilakukan oleh petugas lapangan. Taksiran penyelesaian kemajuan fisik yang dilakukan berdasarkan opname lapangan tidak dapat menjamin keakuratan atas penilaian suatu proyek, sehingga seringkali menyebabkan ketidaksesuaian perkiraan persentase penyelesaian menurut pengawas lapangan dan Site Engineering Manager (SEM) dengan perkiraan perusahaan karena tidak memperhatikan besarnya biaya yang terjadi atau usaha yang telah dicurahkan untuk mencapai tahap penyelesaian pekerjaan proyek dalam periode berjalan, sehingga menyebabkan pendapatan, beban, dan laba konstruksi yang dilaporkan tidak dapat diatribusikan menurut penyelesaian pekerjaan kontrak secara proporsional.

Tabel 1 Estimasi Pendapatan, Beban, dan Laba yang diakui PT X

\begin{tabular}{lrrr}
\multicolumn{1}{c}{ Keterangan } & Akumulasi & $\begin{array}{c}\text { Diakui di } \\
\text { Periode Lalu }\end{array}$ & $\begin{array}{c}\text { Diakui di Periode } \\
\text { Berjalan }\end{array}$ \\
\hline $\begin{array}{l}\text { Tahun Pertama } \\
\begin{array}{l}\text { Pendapatan } \\
\text { Rp 2.160.000.000 x 24.15\%) }\end{array}\end{array}$ & 521.640 .000 & & 521.640 .000 \\
$\begin{array}{l}\text { Beban } \\
\text { Laba kotor } \\
\text { Tahun Kedua }\end{array}$ & 406.080 .000 & & 406.080 .000 \\
$\begin{array}{l}\text { Pendapatan } \\
\text { Rp 2.160.000.000 x 100\%) }\end{array}$ & 115.560 .000 & & 115.560 .000 \\
Beban & 2.160 .000 .000 & 521.640 .000 & 1.638 .360 .000 \\
Laba kotor & 1.728 .000 .000 & 406.000 .000 & 1.321 .920 .000 \\
& 432.000 .000 & 115.560 .000 & 316.440 .000 \\
\hline
\end{tabular}

Sumber: Data Primer Diolah 
Revenue and Expenses Recognition

394

Dalam perhitungan pengakuan pendapatan berdasarkan metode persentase penyelesaian dengan pendekatan progres fisik (physical progress) dalam mengakui pendapatan yang persentasenya ditentukan berdasarkan opname lapangan yang dilakukan oleh petugas lapangan. Taksiran penyelesaian kemajuan fisik yang dilakukan berdasarkan opname lapangan tidak dapat menjamin keakuratan atas penilaian suatu proyek, sehingga seringkali menyebabkan ketidaksesuaian perkiraan persentase penyelesaian menurut pengawas lapangan dan Site Engineering Manager (SEM) dengan perkiraan perusahaan karena tidak memperhatikan besarnya biaya yang terjadi atau usaha yang telah dicurahkan untuk mencapai tahap penyelesaian pekerjaan proyek dalam periode berjalan, sehingga menyebabkan pendapatan, beban, dan laba konstruksi yang dilaporkan tidak dapat diatribusikan menurut penyelesaian pekerjaan kontrak secara proporsional.

Kesesuaian Pengakuan Pendapatan Konstruksi di PT X dengan PSAK 34 Metode Persentase Penyelesaian (Cost to Cost)

Tabel 2 Estimasi Pendapatan, Beban, dan Laba yang diakui PT X

\begin{tabular}{lrrr}
\multicolumn{1}{c}{ Keterangan } & Akumulasi & $\begin{array}{c}\text { Diakui di } \\
\text { Periode Lalu }\end{array}$ & $\begin{array}{c}\text { Diakui di } \\
\text { Periode Berjalan }\end{array}$ \\
\hline $\begin{array}{l}\text { Tahun Pertama } \\
\text { Pendapatan }\end{array}$ & 507.600 .000 & & 507.600 .000 \\
Rp 2.160.000.000 x 23.50\%) & & & \\
$\begin{array}{l}\text { Beban } \\
\text { Laba kotor }\end{array}$ & 406.080 .000 & & 406.080 .000 \\
Tahun Kedua & 101.520 .000 & & 101.520 .000 \\
Pendapatan & & & \\
(Rp 2.160.000.000 x 100\%) & 2.160 .000 .000 & 507.600 .000 & 1.652 .400 .000 \\
Beban & & & \\
Laba kotor & 1.728 .000 .000 & 406.080 .000 & 1.321 .920 .000 \\
\hline
\end{tabular}

Sumber: Data Primer Diolah

Berdasarkan data perhitungan pada Tabel 1 dan Tabel 24 dengan metode pendekatan cost-to-cost, dapat dijelaskan bahwa nilai kontrak merupakan nilai kontrak bersih dari perjanjian, rencana anggaran biaya $(\mathrm{RAB})$ proyek merupakan estimasi biaya-biaya yang akan dikeluarkan sampai dengan penyelesaian proyek kontrak dan estimasi atau taksiran biaya ini dibuat atau ditentukan di awal oleh perusahaan. Biaya proyek berjalan adalah total biaya aktual yang telah dikeluarkan untuk penyelesaian proyek pada periode tersebut. Persentase penyelesaian adalah persentase selesai yang dihitunng dengan pendekatan cost to cost diperoleh dari perbandingan biaya aktual dengan RAB proyek selanjutnya dikalikan seratus persen. Pendapatan yang diakui dihitung dengan cara mengalikan persentase penyelesaian dengan nilai kontrak proyek. Sedangkan laba kotor konstruksi 2016 dan 2017 merupakan selisih antara pendapatan yang diakui dengan biaya aktual yang terjadi.

Tabel 3 Pendapatan dan Beban PT X dengan Metode Kontrak Selesai

\begin{tabular}{lrrr}
\multicolumn{1}{c}{ Keterangan } & Akumulasi & $\begin{array}{c}\text { Diakui di } \\
\text { Periode Lalu }\end{array}$ & $\begin{array}{c}\text { Diakui di } \\
\text { Periode Berjalan }\end{array}$ \\
\hline $\begin{array}{l}\text { Tahun Pertama } \\
\text { Pendapatan }\end{array}$ & 406.080 .000 & & 406.080 .000 \\
$\begin{array}{l}\text { Beban } \\
\text { Laba kotor }\end{array}$ & 406.080 .000 & & 406.080 .000 \\
& - & & \\
Tahun Kedua & & & \\
$\begin{array}{l}\text { Pendapatan } \\
\text { Rp 2.160.000.000 x 100\%) }\end{array}$ & 2.160 .000 .000 & 406.080 .000 & 1.753 .920 .000 \\
$\begin{array}{l}\text { Beban } \\
\text { Laba kotor }\end{array}$ & 1.728 .000 .000 & 406.080 .000 & 1.321 .920 .000 \\
\hline
\end{tabular}

Sumber: Data Primer Diolah 
Jika kondisi untuk menggunakan metode persentase penyelesaian tidak terpenuhi, maka perusahaan opsi terakhir yaitu dengan menggunakan metode kontrak selesai atau biaya terpulihkan dalam mengakui pendapatan dan beban kontrak. PT X menggunakan metode kontrak selesai atau biaya terpulihkan jika hasil pekerjaan tidak dapat diukur dengan andal, maka perusahaan mengakui pendapatan hanya sebesar biaya yang terjadi yang diharapkan dapat terpulihkan. Setelah biaya kontrak diakui, maka perusahaan baru dapat mengakui laba. Jika demikian maka perusahaan akan melaporkan pendapatan dan beban selama tahun pertama sampai tahun kedua seperti pada tabel 3 .

Perbandingan antara Metode Pendekatan Fisik dengan Cost-to-cost dan Metode Kontrak Selesai dalam Mengakui Pendapatan dan Laba Periode Berjalan

Tabel 4 Perbandingan Perhitungan Pengakuan Pendapatan diakui PT X

\begin{tabular}{lccc}
\hline & \multicolumn{2}{c}{ Metode Persentase Penyelesaian } & Metode Kontrak \\
& Physical progress & Cost-to-cost & Selesai \\
\hline Thn. Pertama & Rp 521.640.000 & Rp 507.600.000 & \\
Thn. Kedua & Rp 1.638.360.000 & Rp 1.652.400.000 & Rp 2.160.000.000 \\
\hline
\end{tabular}

Tabel 5 Perbandingan Perhitungan Laba yang diakui PT X

\begin{tabular}{lccc}
\hline & \multicolumn{2}{c}{ Metode Persentase Penyelesaian } & \multicolumn{2}{c}{$\begin{array}{c}\text { Metode Kontrak } \\
\text { Physical progress }\end{array}$} & Cost-to-cost & Selesai \\
\hline Thn. Pertama & Rp 115.560 .000 & Rp 101.520.000 & \\
Thn. Kedua & Rp 316.440 .000 & Rp 330.480.000 & Rp 432.000.000 \\
\hline
\end{tabular}

Berdasarkan perbandingan yang ditampilkan pada Tabel 4 dan 5 dapat diketahui adanya selisih pengakuan pendapatan maupun laba kotor antara metode pendekatan progress fisik yang dilakukan oleh perusahaan dengan metode pendekatan cost-to-cost (persentase penyelesaian) dan metode kontrak selesai (biaya terpulihkan) sebagaimana yang di tentukan oleh PSAK 34 (DSAK, IAI:2014). Pendapatan dan laba yang diakui dengan progress fisik cenderung disajikan lebih tinggi (overstated) karena hanya mengandalkan penilaian atau estimasi kemajuan fisik saja.

Terkait dengan hal tersebut sebaiknya perusahaan di dalam mengakui pendapatan maupun beban-beban menggunakan pendekatan cost-to-cost (persentase penyelesaian) karena menurut pendekatan ini pendapatan kontrak dihubungkan dengan biaya kontrak yang terjadi dalam mencapai tahap penyelesaian tersebut, sehingga pendapatan, beban, dan laba yang dilaporkan dapat diatribusikan menurut penyelesaian pekerjaan secara proporsional. Seperti yang telah disebutkan dalam PSAK 34 (DSAK, IAI:2014), disebutkan bahwa: "Pengakuan pendapatan dan beban dengan memerhatikan tahap penyelesaian suatu kontrak sering disebut sebagai metode persentase penyelesaian. Menurut metode ini, pendapatan kontrak dihubungkan dengan biaya kontrak yang terjadi dalam mencapai tahap penyelesaian tersebut, sehingga pendapatan, beban, dan laba yang dilaporkan dapat diatribusikan menurut penyelesaian pekerjaan secara proporsional. Metode ini memberikan informasi yang berguna mengenai cakupan aktivitas kontrak dan kinerja selama suatu periode".

Metode pengakuan pendapatan dengan pendekatan cost-to-cost (persentase penyelesaian) dalam melakukan pencatatan pendapatan (revenue) berdasarkan perhitungan proporsi biaya kontrak yang dikeluarkan sebagaimana menurut PSAK 34 (DSAK, IAI:2014), yang menyatakan: "Jika tahap penyelesaian ditentukan dengan memerhatikan biaya kontrak yang terjadi pada saat ini, maka hanya biaya kontrak yang mencerminkan pekerjaan yang dilaksanakan dimasukkan dalam biaya.

Hal ini sesuai dengan the matching principle yang menyatakan bahwa biaya yang dikeluarkan harus diakui dalam periode yang sama dengan pendapatan sebagai satu kesatuan. Sehingga pendapatan dan laba kotor konstruksi diakui lebih tepat dalam rangka penyajian laporan keuangan yang wajar yang berguna untuk memberikan informasi lebih akurat dalam pengambilan keputusan, karena dalam PSAK 34 untuk 
Revenue and Expenses Recognition

396

kaitanya tentang pengakuan pendapatan dan biaya kontrak diuraikan sebagai berikut: Jika hasil kontrak konstruksi dapat diestimasi secara andal, maka pendapatan kontrak dan biaya kontrak yang berhubungan dengan kontrak konstruksi diakui masing-masing sebagai pendapatan dan beban dengan memerhatikan tahap penyelesaian aktivitas kontrak pada tanggal akhir periode pelaporan. Taksiran rugi pada kontrak konstruksi tersebut segera diakui sebagai beban kontrak PSAK 34 (DSAK, IAI:2014).

\section{PENUTUP}

Beberapa kesimpulan yang dapat diambil berdasarkan hasil penelitian ini adalah sebagai berikut:

1. Pengakuan pendapatan atas kegiatan usaha merupakan hal yang sangat penting dan sangat berpengaruh terhadap laporan keuangan perusahaan. Jika perusahaan melaporkan pendapatanya terlalu rendah atau terlalu besar, pada laporan keuangannya maka akan berpengaruh terhadap keputusan yang diambil.

2. Berdasarkan pembahasan dan analisis yang telah dilakukan, perusahaan mengakui pendapatan dari kontrak jangka panjang didasarkan pada metode persentase penyelesaian sesuai dengan PSAK 34 dan menggunakan metode pendekatan pada kemajuan fisik (progress fisik) yang dituangkan dalam laporan prestasi poyek yang dibuat oleh Site Enginering Manager (SEM) beserta petugas pengawas lapangan.

3. Dalam hasil tersebut terdapat perbedaan yang signifikan dalam mengakui pendapatan dan laba pada tahun 2016 dan 2017 antara metode persentase penyelesaian pendekatan fisik (progress fisik) dan pendekatan (cost-to-cost). Metode pendekatan fisik mengakui pendapatan dan laba lebih tinggi daripada metode pendekatan cost-to-cost sehingga pendapatan dan laba yang disajikan dalam laporan keuangan menjadi overstatement dan tidak sesuai dengan prinsip konservatisme dalam penyajian laporan keuangan.

4. Metode persentase penyelesaian (cost-to-cost) memberikan gambaran yang lebih wajar dalam mengakui pendapatan jika dibandingkan dengan pendekatan fisik karena pendekatan cost-to-cost mengakui pendapatan dengan memperhatikan besarnya biaya yang terjadi atau biaya yang telah dicurahkan untuk mencapai tahap penyelesaian pekerjaan kontrak selama tahun 2016 dan 2017, sehingga sesuai dengan konsep (the matching principle) dalam rangka penyajian laporan keuangan yang wajar.

\section{DAFTAR PUSTAKA}

Dewan Standar Akuntansi Keuangan. 2015. Pernyataan Standar Akuntansi Keuangan. Penerbit Ikatan Akuntan Indonesia. Jakarta.

Kieso, Donald E.,Weygant, Jerry J., Warfield, Terry D. 2014. Intermediate Accounting IFRS Edition (Second). United States of America: John Wiley \& Sons Inc.

Lisandri. 2016. Analisis Pengakuan Pendapatan dan Beban Kontrak pada Perusahaan Kontraktor PT Nouvalindo Banjarmasin. Jurnal Spread, Vol. 6 No. 2.

Martani, Dwi. 2016. Akuntansi Keuangan Menengah Berbasis PSAK. Buku 2, Salemba Empat. Jakarta.

Merita Dwi Novianti. 2014. Penerapan Metode Pengakuan Pendapatan Kontrak Jangka Panjang pada PT Adhikarya Jaya Mandiri. Jurnal Ilmu \& Riset Akuntansi, Vol. 3 No.8

Muara Dia Astutik. 2015. Penerapan PSAK No. 34 pada Laporan Keuangan PT Multi Sarana Teknik Indonesia. Jurnal Ilmu \& Riset Akuntansi, Vol. 4 No. 10.

Ratunuman, Sisilia Merry. 2013. Analisi Pengakuan Pendapatan dengan Persentase Penyelesaian dalam Penyajian Laporan Keuangan PT. Pilar Dasar. Manado: Jurnal EMBA. Volume 1 No. 3 Universitas Sam Ratulangi Manado.

Rismansyah. 2015. Analisis Pengakuan Pendapatan dan Beban pada PT Wahana Bumi Riau Cabang Palembang. Jurnal Media Wahana Ekonomika, Vol. 12 No. 2: 51-74. 